\title{
CHANGES IN TEXTURE AND FABRIC OF PARTICLES IN GLACIAL TRACTION WITH DISTANCE FROM SOURCE, MÝRDALSJÖKULL, ICELAND
}

\author{
By Ole HUMLUM*
}

(Arctic Station, University of Copenhagen, DK-3953 Godhavn, Greenland)

ABSTRACT. Evolution of sedimentological characteristics for traction debris is investigated along a transport path down-glacier from a subglacial point source at the northern rim of the ice cap Mýrdalsjökull, Iceland. Losses and gains from this path are discussed. Close to mature characteristics as to particle size, shape, roundness, and fabric are developed after only short basal transport, about $500 \mathrm{~m}$, while further transport only results in minor changes. This development is interpreted as the result of selective subglacial lodgement of large particles and/or particles with longitudinal $a$-axis orientation, while particles of median size and/or oblique orientation tend to stay in basal transport. Implications for basal sliding and subglacial sedimentation patterns are discussed.

RÉSUMÉ. Évolution avec la distance à la source, pour un écoulement extensif, de la texture et de la fabrique des particules incluses dans la glace, Mýrdalsjökull, Islande. On a examiné l'évolution des caractéristiques sédimentologiques des dépôts de traction le long d'un émissaire glaciaire, depuis un point-origine sous-glaciaire à la bordure Nord du Mýrdalsjökull en Islande. On discute les pertes et les gains le long de cet émissaire. L'essentiel des caractéristiques de maturité, telles que la taille des particules, leur forme, leur sphéricité et leur orientation cristallographique sont acquises au bout seulement d'un court transport au fond, environ $500 \mathrm{~m}$, tandis que les charriages ultérieurs ne provoquent que des changements mineurs. On interprète ce changement

\section{INTRODUCTION}

Temperate glaciers usually transport the major part of their subglacially derived debris in a basal transport zone (Boulton [ $\left.\left.{ }^{c} 1975\right], 1978\right)$, restricted to a layer 0.05-1 m thick, immediately above the glacier sole, with debris concentrations usually about 2-30\% (Carol, 1947; Lewis, 1960; Kamb and LaChapelle, 1964; Boulton [ ${ }^{\mathrm{C}} 1974$ ], $\left[{ }^{\mathrm{C}} 1975\right.$ ], 1978, 1979; Vivian, 1975; Theakstone, 1979; Humlum, 1981). Debris which comes into contact with the glacier bed is referred to as the traction load, and may be comminuted effectively by failure caused by large interface stresses generated at the glacier sole (Boulton, 1978). Boulders transported as traction load will tend to be rounded and bear several directions of striations, and the traction load as a whole is usually enriched in fines relative to the initial debris because of comminution. Above the basal transport zone, temperate glaciers may transport suspended debris derived from supraglacial sources, the actual amount depending on the character of the terrain surrounding the glacier (Eyles and Rogerson, 1977, 1978; Boulton, 1978; Gomez and Small, 1983).

Observations from recent glaciers demonstrate that the basal zone of traction is probably mechanically very active; but the rate at which this evolution operates is difficult to

*Former address: Department of $\begin{gathered}\text { Geomorphology, } \\ \text { Geographical Institute, University of }\end{gathered}$ Haraldsgade 68,2100 Copenhagen Ø, Denmark. comme le résultat d'un dépôt préférentiel des éléments de grande taille et/ou des éléments dont l'orientation de l'axe- $a$ est longitudinal, tandis que les particules de taille moyenne et/ou d'orientation oblique tendent à rester dans la moraine de fond. On discute les implications qui en résultent pour les modes de glissement au sol et de sédimentation sous glaciaire.

ZusAmmENFAssuNG. Änderungen von Textur und
Gefüge im Gletscher mitgeschleppter Einschlüsse in
abhängigkeit der Entfernung vom Ursprungsort,
Mýrdalsjökull, Island. Längs einer Transportbahn
gletscherabwärts von einer subglazialen, punktförmigen
Quelle am Nordrand der Eiskappe des Mýrdalsjökull in
Island wird die Entwicklung der sedimentologischen
Charakteristiken des mitgeführten Schuttes untersucht.
Verluste und Gewinne auf dieser Bahn werden diskutiert.
Nahezu reife Charakteristiken hinsichtlich der Grösse, der
Form, der Rundung und des Gefüges werden schon nach
kurzem Transport am Untergrund, etwa 500 m, entwickelt,
während der weitere Transport nur zu geringfügigen
Änderungen führt. Diese Entwicklung wird als Ergebnis
selektiver subglazialer Ablagerung grosser Partikel und/oder
von Partikeln mit Längsorietierung der a-Achsen gedeutet,
während Partikel mittlerer Grösse und/oder mit schräger
Orientierung dazu neigen, am Untergrund weitertransportiert
zu werden. Folgerungen für das Gleiten am Untergrund und
für subglaziale Ablagerungsmuster werden diskutiert.

assess because of unknown gains and losses to the basal transport system (Boulton, 1978).

The present paper attempts to supply some knowledge in this respect, considering the evolution of sedimentological characteristics along a well-defined transport path in the basal zone of traction of a temperate glacier. Losses and gains along this path can be estimated to some degree. The glacier investigated is the ice cap Mýrdalsjökull, southern Iceland, where the recent glacial history and debris-transport paths are well known (Humlum, 1981; Krüger and Humlum, 1981; Krüger and Thomsen, 1984).

\section{STUDY AREA}

Mýrdalsjökull is a $596 \mathrm{~km}^{2}$ ice cap, covering the volcanic Katla massif in southern Iceland (Fig. 1). From the subglacial caldera beneath the southern part of Mýrdalsjökull, the most catastrophic jökulhlaups in Iceland are known to be triggered by volcanic eruptions, usually draining beneath the outlet glacier Höfdabrekkujökull to the south-east. Although situated in a very active volcanic area, no jökulhlaups are known from the northern part of the ice cap, called Sléttjökull (Rist, 1967), from where the data presented in this paper were obtained.

Several lines of evidence, e.g. snow temperatures and character of the exposed glacier bed, suggest that Mýrdalsjökull is a temperate ice cap (Humlum, 1981). Furthermore, Björnsson ([1980]) suggested that glaciers in Iceland are of the temperate type.

The northern part of the ice cap, Slettjökull, has at 


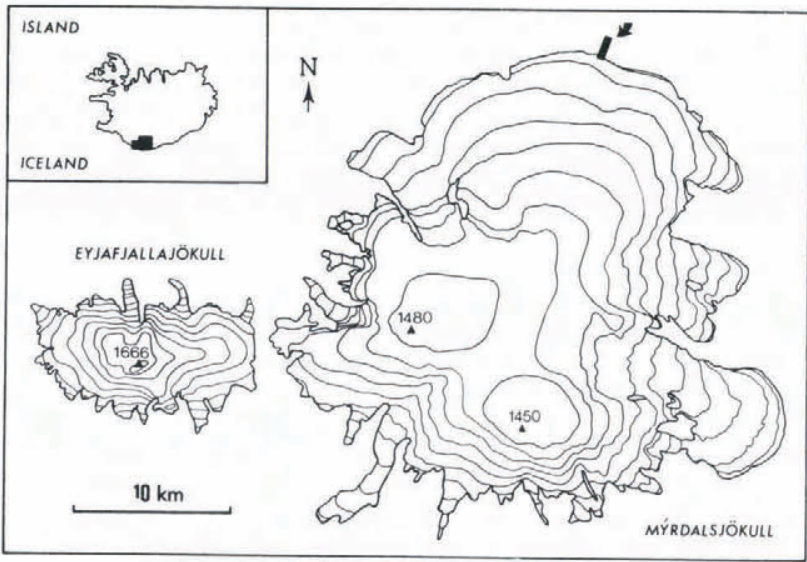

Fig. 1. Location map of Mýrdalsjökull, Iceland. The study area at Sléttjökull (northern part of Mýrdalsjökull) is shown by the arrow.

present a glacier terminus almost $21 \mathrm{~km}$ in length, underlain by lodgement till, glacio-fluvial sediments and tephra. The pro-glacial area has a gentle relief and is situated about $600 \mathrm{~m}$ a.s.l. Since about A.D. 1900, when this part of the ice cap reached its maximum extent in the Holocene, the glacier has retreated $1.5-2 \mathrm{~km}$, exposing large areas of fluted ground moraine (Humlum, 1981; Krüger and Humlum, 1981). The ground moraine has the form of flats and drumlinized areas (Krüger and Thomsen, 1984).

Transport of debris by Slettjökull is, with a few and unimportant exceptions, restricted to the basal transport zone only (Humlum, 1981), which in most cases is $20-50 \mathrm{~mm}$ thick at the glacier terminus. Only a few small nunataks rise above the glacier surface and almost all debris present in the glacier appears to be subglacially derived. This situation obviously provides a good opportunity for a study on sedimentological characteristics due to basal transport.

The study area is located in the central part of the glacier terminus (Fig. 1). Here, an isolated bedrock knob rises about $100 \mathrm{~m}$ above the ground-moraine plain (Fig. 2). The ground dimensions of the knob are about $250 \mathrm{~m}$ $250 \mathrm{~m}$. On air photographs from 1945, glacier ice is seen covering the bedrock knob, whose location is indicated by a conspicuous crevasse pattern. The bedrock of this knob consists of a light yellow rhyolitic rock type, in contradistinction to the greyish colour otherwise characterizing the bedrock (young grey basalts and pumice) in this area. These two different colours are inherited by
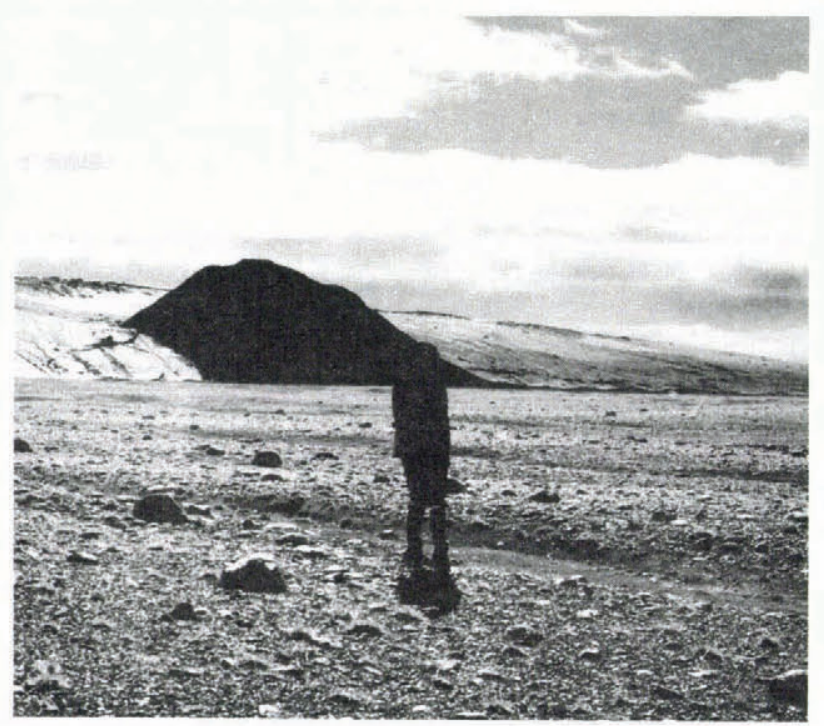

Fig. 2. General view of the ground-moraine plain beyond the northern margin of Mýrdalsjökull. The study area is located down-glacier of the bedrock knob in the centre of the photograph.

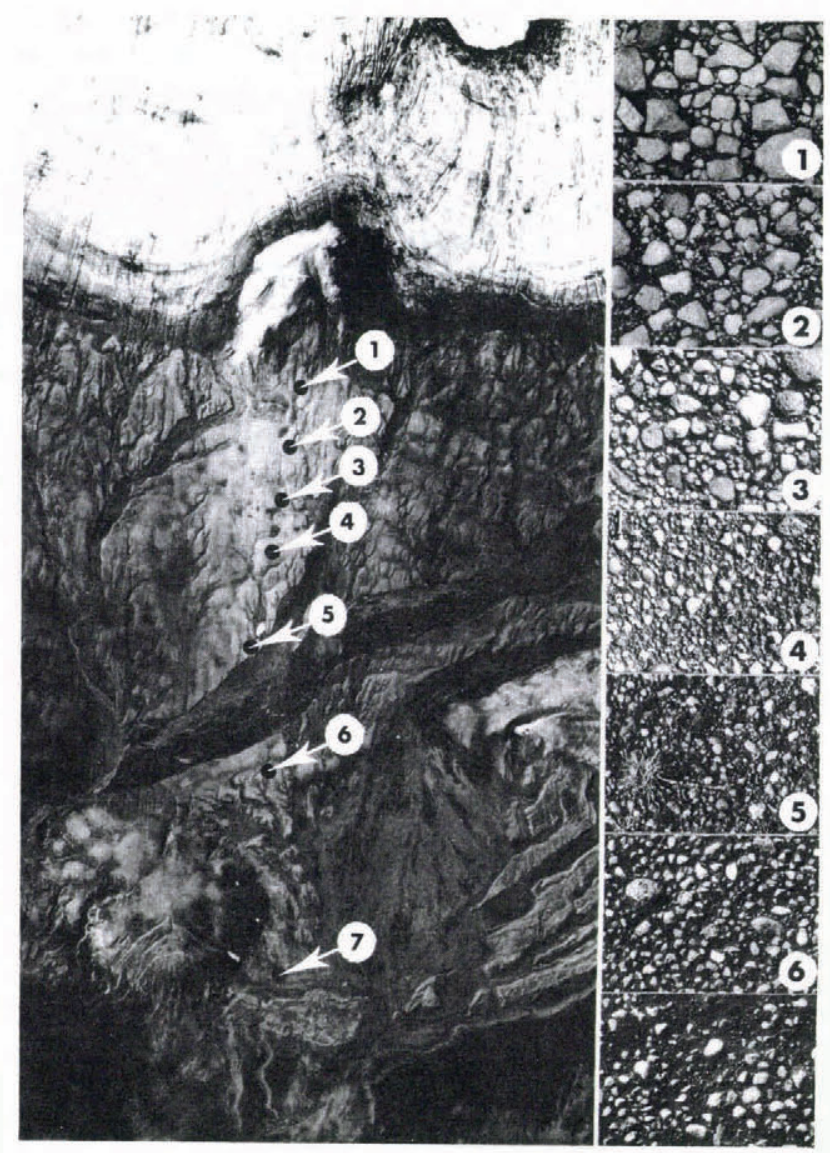

Fig. 3. Aerial view of the study area (Landmaelingar Islands, Icelandic Geodetic Survey, 1979). Locations of seven test sites in the tail of the bright till down-glacier of the bedrock knob are indicated by arrows. The outermost moraine ridge is seen just above the bottom of the photograph. North is towards the lower right-hand corner. To the right are shown $30 \mathrm{~cm} \times 20 \mathrm{~cm}$ sections from each sampling site.

the glacial sediments and a distinct zone of light yellow till extends down-glacier from the bedrock knob to the outermost moraine (Fig. 3).

Supraglacial melt-water streams have eroded numerous channels into the till plain in the study area and all profiles show a uniform stratigraphy; loose volcanic debris, partly fluvially transported, overlain by and interfingering with glacio-fluvial sediments, and one (two) fine-grained lodgement till(s) with occasional boulders (Krüger and Thomsen, 1984). Virtually all boulders in the till(s) are striated and many display a stoss-and-lee side form (Boulton, [c 1974 ], 1978; Krüger, 1979; Sharp, 1982). Furthermore, several of these blocks have a double stoss-lee form in the sense that two independent stoss-and-lee forms are present with opposite orientations on the lower and upper part of the boulder, respectively. Clasts such as these are probably a good criterion for classifying the till as a lodgement till (see Krüger, 1984). The uppermost layer in the stratigraphy is represented by a one-particle layer consisting of light yellow stones and boulders $1-15 \mathrm{~cm}$ in diameter (Fig. 3). This surface layer corresponds to similar (grey) layer covering the ground moraine on either side of the bedrock knob and which was interpreted by Humlum (1981) as a type of melt-out till composed of a particle population which escaped lodgement while in traction against the glacier bed. The light yellow colour characterizing the surface layer down-glacier from the bedrock knob indicates that most particles were derived from this part of the glacier bed, which may be considered as a point source due to its small dimensions.

To investigate the mechanical effect of basal transport, particles from the surface layer were studied in some detail 
as to size, shape, roundness, striations, and fabric along a flow line from the point source towards the outermost moraine. Seven sampling sites were chosen, as shown in Figure 3, and at each site the above characteristics were measured on the 25 largest particles found inside the $2 \mathrm{~m} \mathrm{x}$ $2 \mathrm{~m}$ sites. Occasional greyish particles present in the surface layer were excluded from the analysis, as these were probably derived from farther up-glacier in relation to the bedrock high. The former ice-flow direction was determined as being parallel to the glacial flutes at the individual sites.

\section{PARTICLE SIZE}

Figure 3 shows part of each of the investigated sites as seen from above. A distinct decrease in maximum particle size is readily apparent as transport distance increases. Figure 4 shows this in greater detail, giving the length of the $a-, b-$, and $c$-axes, and the approximate volumes represented by the 25 largest particles at each site. Figure 5 shows the mean particle dimension, $\bar{d}$, as a function of the basal-transport distance. All axes are reduced as transport distance increases; however, the greatest amount of reduction occurs between sites 1 and 4 (about a 50\% reduction from the initial values), i.e. within the first $500 \mathrm{~m}$ of basal transport. No further significant changes are apparent during the subsequent $1200 \mathrm{~m}$ of transport. The same tendency is also shown by the mean diameter $\bar{d}$ (Fig. 5); a marked decrease from $11 \mathrm{~cm}$ to $6 \mathrm{~cm}$ within the first $500 \mathrm{~m}$ of basal transport and only further insignificant changes as the transport distance increases beyond this value.
Also, the volume index (right-hand column of Figure 4) dramatically indicates the overall importance of the first $500 \mathrm{~m}$ of basal transport. The mean volumes of the 25 largest particles are reduced to about $15 \%$ of their initial values. This may be due to preferred lodgement of the large particles, crushing of the large particles into smaller fragments, abrasion, or a combination of these mechanisms.

\section{PARTICLE SHAPE}

All investigated particles were classified in one of four shape categories: rod, blade, disc, and sphere (Table I), using the classification system of Zingg (1935). The observations were plotted on $c / b-b / a$ diagrams (Fig. 6), which were then contoured for frequency, using a $1 \%$ counter. In Figure 6 there are areas without observations (white) and areas with observations (black), respectively, using the $1 \%$ contour as an envelope. No distinct tendency is apparent as to shape as basal-transport distance increases; only a weak drift towards dominance of more equidimensional particles may be present. However, this point remains inconclusive and would probably require a substantially larger sample size for clarification.

\section{ROUNDNESS}

The roundness (angularity) of the sampled particles was determined using the comparison chart of Powers (1953). This classification describes particle roundness as a series of six stages of development from very angular to very rounded. Initially, at site 1 the particles are dominantly

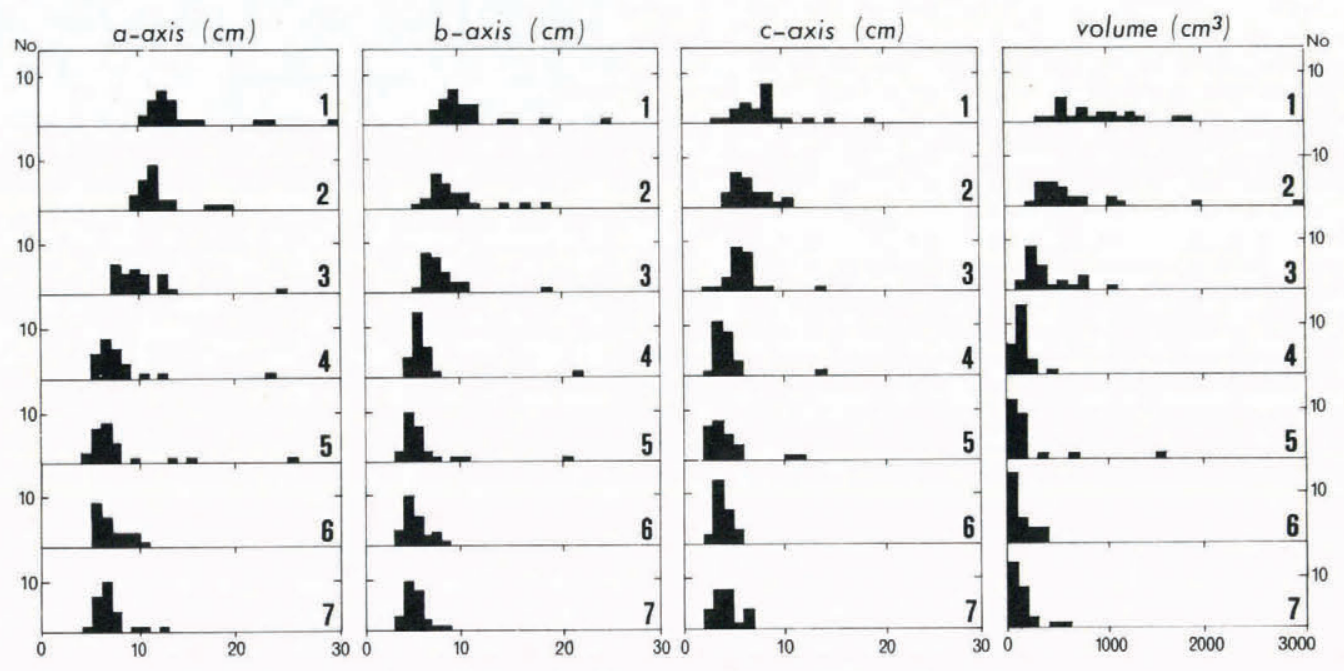

Fig. 4. Histograms showing the dimensions and approximate volumes of the 25 largest particles sampled at each site. Volumes are calculated as $a \times b \quad x \quad c$.

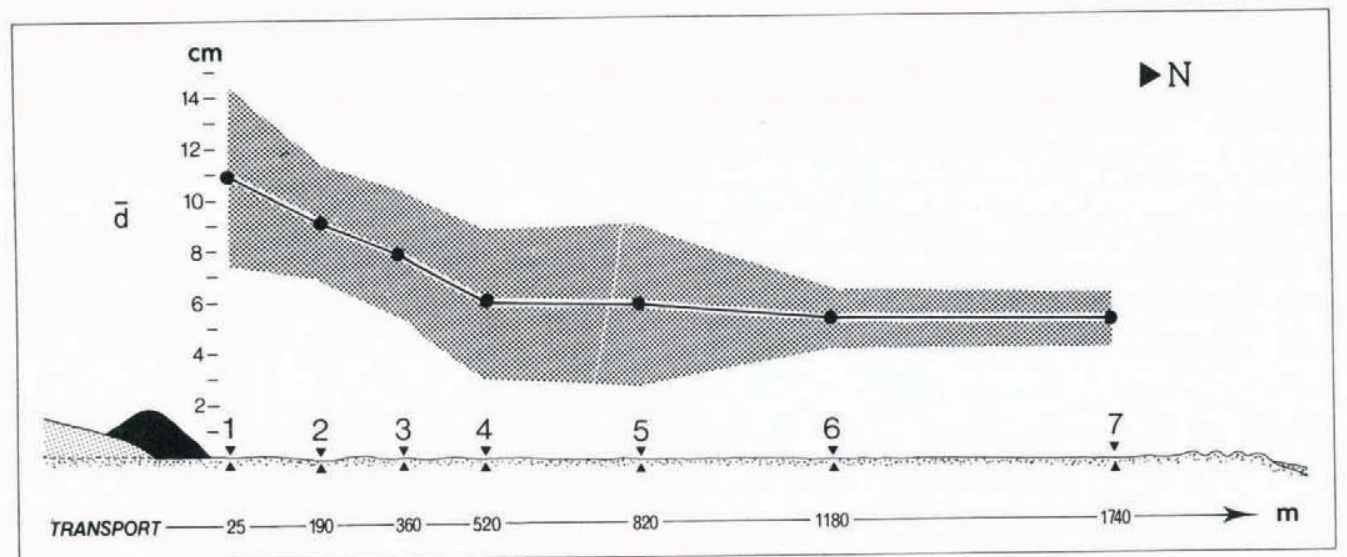

Fig. 5. Down-glacier decrease of the mean dimension, $\bar{d}$, of the 25 largest particles sampled at each site. The shaded area indicates the range of standard deivation on each side of $\bar{d}$. 
TABLE I

$\begin{array}{crccc}\begin{array}{c}\text { Particle shape } \\ \%\end{array} & \text { Rod } & \text { Blade } & \text { Disc } & \text { Sphere } \\ \text { Station 1 } & 12 & 4 & 28 & 56 \\ \text { Station 2 } & 24 & 0 & 32 & 44 \\ \text { Station 3 } & 20 & 0 & 20 & 60 \\ \text { Station 4 } & 8 & 0 & 32 & 60 \\ \text { Station 5 } & 4 & 0 & 44 & 52 \\ \text { Station 6 } & 16 & 0 & 24 & 60 \\ \text { Station 7 } & 20 & 4 & 16 & 60\end{array}$

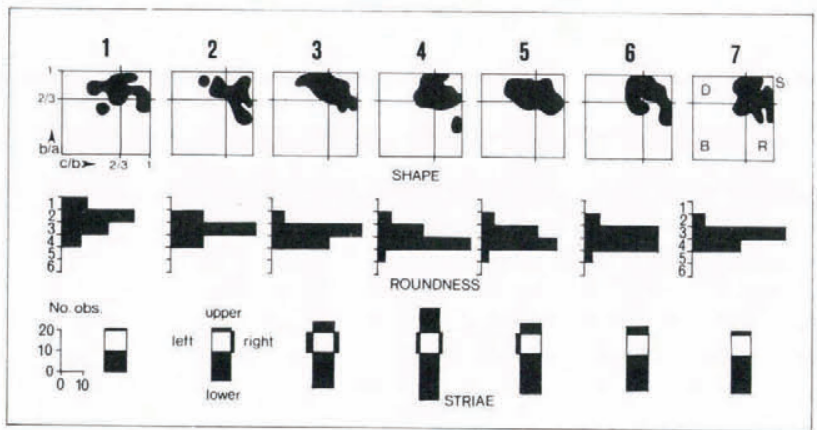

Fig. 6. Shape, roundness, and distribution of striae on the 25 largest particles sampled at each site. $B$, blades; $D$, discs; $R$, rods; S, spheres (Zingg, 1935). Roundness is according to Powers (1953); 1, very angular, 6, very rounded. Locations of striae are given as present on upper, lower, left, and right surfaces. Left and right are in relation to the down-glacier direction. Further description and discussion are in the text.

angular but, as transport distance increases, the main tendency is moved towards sub-angular particles (Fig. 6). The major part of the observed increase in roundness occurs between sites 1 and 4, within the first $500 \mathrm{~m}$ of transport distance.

\section{ABRASION}

Several of the particles sampled showed striae and abrasional facets, as evidence of basal transport (Table II and Fig. 6). Close to the bedrock knob, $40 \%$ of the particles bear signs of abrasion with a clear dominance of these being located at the lower surface. As transport distance increases, abrasional signs become increasingly more common, reaching a maximum of about $92 \%$ at site 4 , $520 \mathrm{~m}$ down-glacier from the source. Almost $90 \%$ of the particles sampled bear signs of abrasion - mainly in the form of striae - on their lower surfaces, and about $50 \%$ on the upper surfaces. Generally speaking, on individual particles, striae on different surfaces are parallel to each other. At all sites, striae on the vertical sides are less frequent than striae in other positions, indicating that most particles attained a relatively stable orientation while in traction against the glacier bed. Furthermore, it also

TABLE II

Surface striated
$\%$

$\begin{array}{rrrrrr}\text { Station } 1 & 40 & 4 & 40 & 4 & 0 \\ \text { Station } 2 & 56 & 8 & 56 & 8 & 4 \\ \text { Station } 3 & 68 & 20 & 68 & 20 & 20 \\ \text { Station } 4 & 92 & 48 & 88 & 44 & 8 \\ \text { Station } 5 & 76 & 20 & 76 & 20 & 8 \\ \text { Station } 6 & 68 & 16 & 68 & 16 & 0 \\ \text { Station } 7 & 72 & 8 & 72 & 8 & 0\end{array}$

indicates that no major re-orientation due to frontal melt-out has taken place. This conclusion is supported by observations on particles melting out slowly from basal ice along the present glacier margin, which revealed only minor re-orientations during this process. This could well be a specific feature of melt-out tills at Sléttjökull; because of the restricted thickness of the basal transport zone (20-50 mm), most of the particles sampled were initially in contact with the glacier bed. Furthermore, most of these rested on a well-developed lower-surface facet.

From site 4 towards the outermost moraine, the frequency of striae decreases to about $70 \%$, with an upper-surface location of striae becoming rare. The difference in frequency of abrasional signs on upper and lower surfaces is real and not the result of subaerial weathering, as exposed bedrock surfaces near the outer moraines display well-preserved striae.

\section{FABRIC PATTERNS}

Preferred orientation of the sampled particles was investigated by two-dimensional macrofabric analysis. Only the horizontal orientation of $a$-axes was measured, because the above observations indicated that re-orientation associated with frontal melt-out - although in general small - was mainly in the vertical plane. The analyses are presented as rose diagrams (Fig. 7) contoured by a modified Kamb (1959) procedure, details of which have been given by Humlum (1981).

The fabric analyses apparently fall into two groups. Sites $1,5,6$, and 7 are characterized by a somewhat dispersed pattern with a tendency towards a weak density peak oblique to the glacier flow. This pattern is almost identical to that found by Humlum (1981, fig. 8) for particles derived from the basal transport zone sampled along the northern margin of Mýrdalsjökull, and which was suggested as being typical for a residual particle population derived by frictional sorting while in traction against the glacier bed. The fabrics at sites 2,3 , and 4 , on the other hand, all show clear longitudinal density peaks resembling the pattern typical for lodgement tills in the area (Humlum, 1981, fig. 9). The implications of these observations are discussed below.

\section{DISCUSSION}

Figure 8 is a composite diagram showing the evolution of all observed sedimentological characteristics as functions of the basal transport distance. The striking impression is that a basal transport distance of about $500 \mathrm{~m}$ is apparently sufficient to produce close-to-mature or stable characteristics; this is especially pronounced for particle dimension, angularity (roundness), and distribution of striae but somewhat less clear for shape and fabric. This rapid evolution of mature (or stable) characteristics points towards significant comminution and/or sorting associated with transport in the basal transport zone. Combining the observations, it appears possible to get some indication of the behaviour of individual clasts while in traction against the glacier bed.

First, it is necessary to consider the relative importance of potential losses and gains along a flow line down-stream from the bedrock knob. Due to the high geothermal heat flow and the maritime climate in this part of Iceland, it is probably safe to reject large-scale basal net freezing anywhere along the glacier-bed interface of Mýrdalsjökull. It would rather seem that basal net melting is the normal situation, which explains the thin basal transport zone observed along the entire $21 \mathrm{~km}$ glacier terminus. The geothermal heat flow in the study area is at least $5 \mu \mathrm{cal}$ $\mathrm{cm}^{-2} \mathrm{~s}^{-1}\left[21 \mu \mathrm{J} \mathrm{cm}^{-2} \mathrm{~s}^{-1}\right]$ (Lee, 1970) and, with the amount of energy dissipated by the sliding motion, this causes melting from the sole. A somewhat low value of $25 \mathrm{~m} /$ year is adopted for the sliding velocity because no actua measurement exists, and the mean basal shear stress is assumed to be about $10^{5} \mathrm{~N} / \mathrm{m}^{2}$. However, with these conservative estimates, about $3 \mathrm{~cm}$ of ice are found to be lost from the glacier sole each year, providing the ice was initially at the pressure-melting point. A basal melting rate 


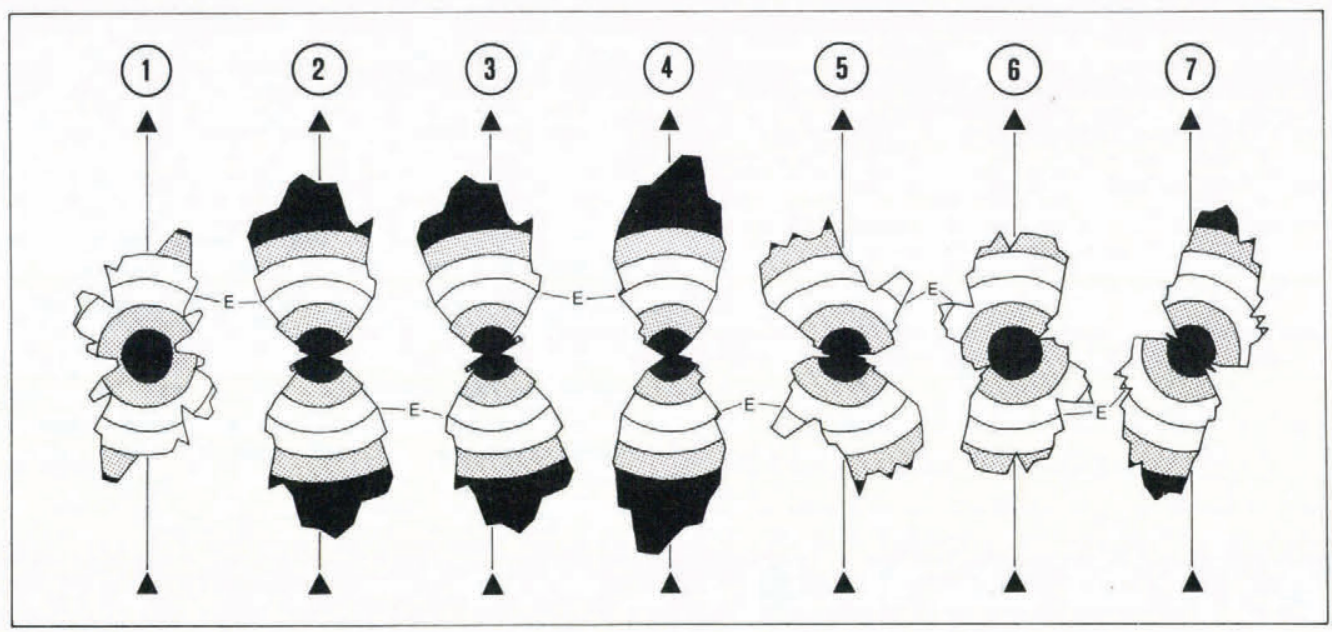

Fig. 7. Horizontal rose diagrams for the fabric (a-axes) of the 25 largest particles sampled at each site. Diagrams are contoured by using a counter of a size chosen so that, if the population lacks preferred orientation, the number $E$ of observations expected to fall within the counter is three times the standard deviation, $\sigma$, of the number that will actually fall within the counter by random sampling of the data. Observed densities that deviate from $E$ by more than twice the standard deviation for random orientation are assumed in the present paper as likely to be significant. particularly if significant high or low densities are clustered in one part of the diagram (cf. Kamb. 1959). Observed densities are contoured at intervals of $\sigma$, the expected density $E$ for no preferred

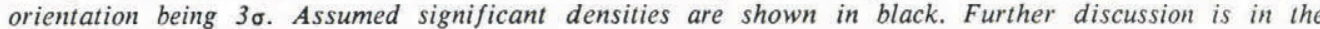
text.

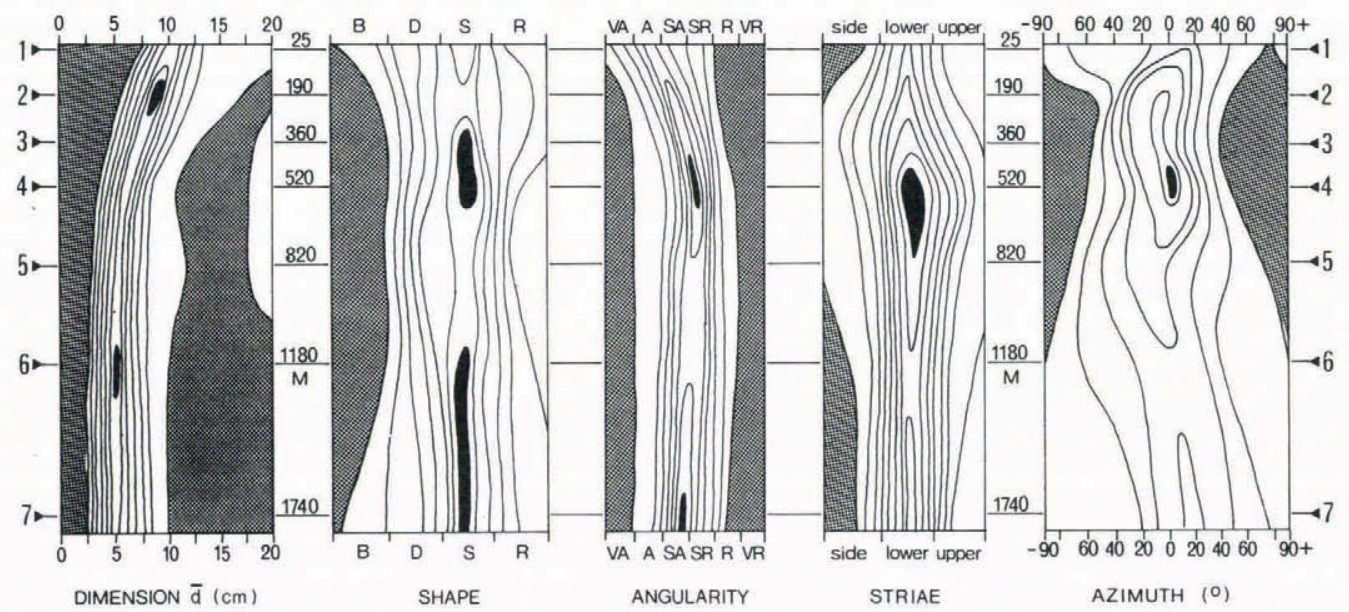

Fig. 8. Composite diagram showing the evolution of sedimentological characteristics as a function of basal-transport distance. The source is at the top of the diagrams. Designations are the same as those used in the preceding figures. Isolines are drawn at 10\% intervals in the diagrams for dimension, shape, angularity, and striae. In the fabric diagram, isolines are drawn at $15 \%$ intervals. Areas without observations are shaded. Discussion is in the text.

of this magnitude probably ensures that debris derived from subglacial sources usually tends to stay close to the glacier sole. Large-scale incorporation of glacier-bed material is therefore considered unlikely except where the glacier flows over large obstacles such as the bedrock knob. At locations like this, flow lines may diverge from the bed on a local scale due to flanking ice moving more rapidly into metre-sized lee-side cavities rather than ice flowing over these medium-sized obstacle crests (Boulton, [ $\left.{ }^{\mathrm{C}} 1974\right]$ ). Medium-sized obstacles are envisaged here as being superimposed on large-scale obstacles such as the bedrock knob (Fig. 2).

Generally speaking, possible gains from the glacier bed along basal transport paths down-glacier from the bedrock knob can be ignored for the purpose of the following discussion. Perhaps exceptional flow lines over the bedrock knob have transported some debris into suspension from a subglacial position, as outlined above. This material somewhat confuses the sedimentological situation as it moves little by little downwards and contaminates the traction load due to basal melting. The importance of this process cannot easily be evaluated but, if it has been operating on any significant scale in the actual situation, the influence would clearly be to make the apparent evolution of the sedimentological characteristics appear less distinct than in the absence of contamination. This should be borne in mind when reading the following discussion, which in consequence of the above will concentrate on losses from the zone of traction to the glacier bed along flow lines down-stream from the bedrock knob.

Initially, at site 1 (25 m transport), striated clasts are few, angularity is high and their fabric somewhat dispersed. At site 2 (190 m transport), striated particles are more frequent, $56 \%$ against $40 \%$, a longitudinal density peak is present, and the mean particle dimension (of 25 largest particles) has decreased from about $11 \mathrm{~cm}$ to $9 \mathrm{~cm}$. This development continues through site 3 to site $4(520 \mathrm{~m}$ transport), where an apparent mean particle size of about 
$6 \mathrm{~cm}$ is reached, a distinct longitudinal fabric is present, and striated surfaces are the rule rather than the exception $(92 \%)$. Angularity has decreased to a stage between sub-angular and sub-rounded. Furthermore, of importance is the fact that striae are present on both upper and lower surfaces of almost half the particles sampled (Table II).

On the basis of the above observations, the following scenario can be suggested: fresh debris derived subglacially from the bedrock knob is characterized by a wide range of particle sizes and a dispersed fabric pattern. Subsequent to incorporation into the basal transport zone, this debris behaves according to the frictional laws controlling the tractional load. The particles are therefore being retarded in relation to the surrounding glacier ice, and striae and facets develop on their lower surfaces as they are dragged along the glacier bed. Large particles and/or particles with a longitudinal orientation appear to be retarded more than other particles, and are eventually lodged against the glacier bed after only a short transport distance $(200-500 \mathrm{~m})$. This would explain why the particles sampled between sites 2 and 4 are dominated by longitudinal orientations and, in fact, most of these particles at the time of deglaciation were probably part of the lodgement till beneath the glacier rather than belonging to debris still in traction. The coarse surface layer may therefore be of a more complex nature than envisaged by Humlum (1981). This is discussed further below. Lodged particles act as part of the glacier bed and are subsequently abraded on their upper surfaces, which in combination with the preceding basal transport explains the frequent both top-and-bottom location of striae on clasts found along this part of the transport path, as well as explaining blocks with double stoss-lee forms found in the lodgement till beneath (see Krüger, 1984).

As large particles and/or particles with a longitudinal orientation are selectively being lodged between sites 2 and 4, particles such as these should consequently be rare down-stream of site $4(520 \mathrm{~m})$, provided debris in the zone of traction is not seriously contaminated by fresh debris entering from the zone of suspension above. Apparently, this was the case in the study area, because down-stream of site 4 the sedimentological situation changes as predicted in consequence of the above interpretation. Both clast dimension and angularity only change little with further transport; striae are still frequent on the lower surfaces of particles but now become less frequent in the top position. This indicates that most of the particles sampled beyond site 4 were still in basal transport at the time of deglaciation. The longitudinal fabric pattern is again superseded by a dispersed pattern, with a tendency for a weak density peak to drift into an oblique position as transport continues. Having passed site 4, which in the present case clearly represents a "critical" basal transport distance, debris in the zone of traction is depleted of large particles and/or particles with a longitudinal orientation and consists mainly of particles with size-orientation characteristics that counteract the tendency towards lodgement at the prevailing subglacial pressure-velocity conditions. At Sléttjökull, a mean particle dimension of about $5 \mathrm{~cm}$, in combination with an oblique $a$-axis orientation, appears to characterize this residual population. The particle population thus developed is almost identical to that described by Humlum (1981) as being typical of the basal transport zone along the northern margin of Mýrdalsjökull.

Abrasion is clearly of importance, as is shown by striae and facets, and also crushing of large particles into smaller fragments may well be of equal importance in connection with the observed decreases in mean particle dimension with increasing transport distance. It is, however, difficult to understand how these processes alone should be responsible for the overall sedimentological evolution outlined above; this fact indicates the probable importance of supplementary subglacial phenomena such as the size-orientation sorting process suggested here.

\section{CONCLUSION AND IMPLICATIONS FOR BASAL SLIDING}

The observations at Sléttjökull point towards the importance of both particle size and particle orientation in regard to mechanisms controlling subglacial lodgement versus basal transport. Particles of median size and/or oblique $a$-axis orientation tend to stay in basal transport, while large and (probably) smaller particles, and/or particles with a longitudinal orientation, tend to lodge more readily. With this in mind, the fact that lodgement tills are usually characterized by large amounts of fines (the product of comminution) with occasional larger clasts, heavily striated on their upper surfaces and sometimes with double stoss-lee forms, is not surprising; neither is the dominance of longitudinal fabric patterns in lodgement tills. Altogether, several of the observations made at Sléttjökull appear to be totally compatible with the essentials of the frictional lodgement theory proposed by Boulton ([ $\left.\left.{ }^{c} 1975\right]\right)$.

The pavement beyond the margin of Sléttjökull appears to be of a more complex origin than proposed by Humlum (1981). Within a $500 \mathrm{~m}$ zone down-glacier from the bedrock source, the pavement is dominated by particles lodged against the glacier bed, while particles still in traction at the time of deglaciation are dominant beyond $500 \mathrm{~m}$. In the study area, about $500 \mathrm{~m}$ of basal transport is therefore sufficient to produce mature or stable sedimentological characteristics. This "critical" transport distance may well be specific for Sléttjökull and will probably depend in general on debris lithology, glacier thickness, sliding velocity, hydraulic transmissibility of the glacier bed, the amount of subglacial water and the rate of its production, as well as several other factors. However, the present study indicates that mature or stable sedimentological characteristics may be developed for debris in basal transport after only a very short transport distance. This is in agreement with Drake (1972), who demonstrated that basal till pebbles attained an equilibrium roundness value within 1 mile $[1.6 \mathrm{~km}]$ of their source in New Hampshire, U.S.A.

The findings of the present study, although based on rather small samples, may have some implications for theories on basal sliding. As more energy is expended by temperate glaciers in moving around fixed subglacial obstacles than is done by movement relative to obstructions of an identical size but in basal transport (cf. Boulton, [ $\left.\left.{ }^{c} 1974\right]\right)$. the sorting mechanism outlined above may clearly have an influence on the rate of basal sliding. Attention should also be directed towards the prediction by Hallet (1981) that the sliding rate will be influenced by the amount of debris at the glacier bed.

Consider the debris content in a basal flow path down-glacier relative to a bedrock knob yielding fresh debris. This debris is initially characterized by a wide size range of particles and a dispersed fabric pattern. Each particle in traction against the glacier bed acts a moveable subglacial obstruction. Large particles and/or particles with a longitudinal orientation are retarded more relative to the basal ice, and the glacier expends much energy in moving around them. This is less so for particles which farther down-glacier will be forming the residual load, because the ice velocity relative to these particles is comparatively small.

Particles with a large retardation are probably lodged selectively only after short basal transport $(500 \mathrm{~m}$ in the above example) down-glacier from the sediment source. Between the source and the "critical" distance the glacier-bed interface offers great resistance to basal sliding; this is partly because of the overall heterogeneous traction load and partly because some particles are being lodged against the glacier bed, and thus act as fixed subglacial obstructions. Glacier sliding along this part of the transport path is therefore considered likely to be somewhat sluggish and for this reason flow lines will converge down-glacier of subglacial point sources. Subglacial net sedimentation is therefore expected to be above average, partly for the reasons given above and partly as a result of the high degree of bed roughness which itself may induce lodgement.

Beyond the critical transport distance, debris in the basal transport zone is depleted of large clasts and, if local gains are small or nil, the traction load from this point is dominated by particles which move readily over the glacier bed. Resistance to sliding is low because of low internal friction in the basal transport zone and because of the low degree of bed roughness. Subglacial net sedimentation will also be low. 
This scenario ignores the effects of changing effective stresses at the glacier-bed interface, which themselves have an influence upon sliding and the tendency towards lodgement (Boulton, $\left[{ }^{\mathrm{C}} 1975\right]$ ) but, even so the potential connection between sedimentological characteristics of the traction load and the rate of basal sliding, as well as the subglacial net sedimentation, is obvious. More comprehensive work on this topic is clearly needed.

\section{ACKNOWLEDGEMENTS}

The Science Research Council of Iceland is thanked for permission to work at Mýrdalsjökull. Thanks are also due to the Danish Natural Research Council, who provided a grant which made the investigations possible. The work was carried out in 1982 as a member of the Danish Mýrdalsjökull Research Group under the direction of $\mathrm{J}$. Krüger, Geographical Institute, University of Copenhagen. Discussions with all members of the research group are greatly appreciated. This paper was prepared while serving as scientific director of the Arctic Station, University of Copenhagen, Greenland, and is publication No. 91 of the Arctic Station.

\section{REFERENCES}

Björnsson, H. [1980.] Glaciers in Iceland. Jökull, Ár 29, 1979 , p. $74-80$

Boulton, G.S. [ ${ }^{c_{1974}}$.] Processes and patterns of glacial

erosion. (In Coates, D.R., ed. Glacial geomorphology. Binghamton, State University of New York, p. 41-87.)

Boulton, G.S. [ $\left.{ }^{c} 1975.\right]$ Processes and patterns of subglacial sedimentation: a theoretical approach. (In Wright, A.E., and Moseley, F., ed. Ice ages: ancient and modern. Liverpool, Seel House Press, p. 7-42. (Geological Journal Special Issue No. 6.))

Boulton, G.S. 1978. Boulder shapes and grain size distribution of debris as indicators of transport paths through a glacier and till genesis. Sedimentology, Vol. 25, No. 6, p. 773-99.

Boulton, G.S. 1979. Processes of glacier erosion on different substrata. Journal of Glaciology, Vol. 23, No. 89, p. 15-38.

Carol, H. 1947. The formation of roches moutonnées. Journal of Glaciology, Vol. 1, No. 2, p. 57-59.

Drake, L.D. 1972. Mechanisms of clast attrition in basal till. Geological Society of America. Bulletin, Vol. 83, p. 2159-66.

Eyles, N., and Rogerson, R.J. 1977. Glacier movement, ice structures, and medial moraine form at a glacier confluence, Berendon Glacier, British Columbia, Canada. Canadian Journal of Earth Sciences, Vol. 14, No. 12, p. 2807-16.
Eyles, N., and Rogerson, R.J. 1978. Sedimentology of medial moraines on Berendon Glacier, British Columbia, Canada: implications for debris transport in a glacierized basin. Geological Society of America. Bulletin, Vol. 89, No. 11 , p. 1688-93.

Gomez, B., and Small, R.J. 1983. Genesis of englacial debris within the lower glacier de Tsidjiore Nouve, Valais, Switzerland, as revealed by scanning electron microscopy. Geografiska Annaler, Vol. 65A, Nos. 1-2, p. 45-51.

Hallet, B. 1981. Glacial abrasion and sliding: their dependence on the debris concentration in basal ice. Annals of Glaciology, Vol. 2, p. 23-28.

Humlum, O. 1981. Observations on debris in the basal transport zone of Mýrdalsjökull, Iceland. Annals of Glaciology, Vol. 2, p. 71-77.

Kamb, W.B. 1959. Ice petrofabric observations from Blue Glacier, Washington, in relation to theory and experiment. Journal of Geophysical Research, Vol. 64, No. 11, p. 1891-909.

Kamb, W.B., and LaChapelle, E.R. 1964. Direct observation of the mechanism of glacier sliding over bedrock. Journal of Glaciology, Vol. 5, No. 38, p. 159-72.

Krüger, J. 1979. Structures and textures in till indicating subglacial deposition. Boreas, Vol. 8, No. 3, p. 323-40.

Krüger, J., and Humlum, O. 1981. The proglacial area of Mýrdalsjökull with particular reference to Slettjökull and Höfdabrekkujökull: general report on the Danish geomorphological expedition to Iceland, 1977. Folia Geographica Danica, Tom. 15, No. 1.

Krüger, J., and Thomsen, H.H. 1984. Morphology, stratigraphy, and genesis of small drumlins in front of the glacier Mýrdalsjökull, south Iceland. Journal of Glaciology, Vol. 30, No. 104, p. 94-105.

Lee, W.H.K. 1970. On the global variations of terrestrial heat-flow. Physics of the Earth and Planetary Interiors, Vol. 2, No. 5, p. 332-41.

Lewis, W.V., ed. 1960. Investigations on Norwegian cirque glaciers. London, Royal Geographical Society. (R.G.S. Research Series, No. 4.)

Powers, M.C. 1953. A new roundness scale for sedimentary particles. Journal of Sedimentary Petrology, Vol. 23, No. 2, p. $117-19$

Rist, S. 1967. The thickness of the ice cover of Mýrdalsjökull, southern Iceland. Jökull, Ár 17, p. 237-42.

Sharp, M.J. 1982. Modification of clasts in lodgement tills by glacial erosion. Journal of Glaciology, Vol. 28, No. 100, p. 475-81.

Theakstone, W.H. 1979. Observations within cavities at the bed of the glacier Østerdalsisen, Norway. Journal of Glaciology, Vol. 23, No. 89, p. 273-81.

Vivian, R.A. 1975. Les glaciers des Alpes occidentales. Grenoble, Imprimerie Allier.

Zingg, T. 1935. Beitrag zur Schotteranalyse. Die Schotteranalyse und ihre Anwendung auf die Glattalschotter. Schweizerische Mineralogische und Petrographische Mitteilungen, Nr. 15, p. 38-140. 